\title{
Laryngeal Leiomyosarcoma
}

National Cancer Institute

\section{Source}

National Cancer Institute. Laryngeal Leiomyosarcoma. NCI Thesaurus. Code C6022.

An aggressive malignant smooth muscle neoplasm, arising from the larynx. It is characterized by a proliferation of neoplastic spindle cells. 